Check for updates

1 The BMJ

2 Stanford University School of Medicine

aprice@bmj.com

Essay, doi:10.1136/bmj.n1803

Cite this as: BMJ 2021;374:n1906

http://dx.doi.org/10.1136/bmj.n1906

Published: 10 August 2021

\title{
Commentary: My pandemic grief and the Japanese art of kintsugi
}

\section{Grief is an opportunity to offer empathy by honouring brokenness to support healing, writes Amy Price}

\author{
Amy Price patient editor for research and senior research scientist ${ }^{1}, 2$
}

After the loss of my husband to covid-19, I kept working and tried not to think about it, confident that grief was part of life and time would heal. ${ }^{1}$ After all, I signed on for the marriage knowing one of us would die first. Even though our last words were, "I love you," my grieving did not go as planned. I find I am not alone. ${ }^{2}$

Grief's pain is raw, chronic, unremitting, and cumulative, and we become isolated. Negative thoughts are etched below consciousness. There is no respite from the things we can't unsee. Without joy, we identify as the problem instead of the problem solver. In pain we can react in anger, freeze in confusion, or retreat, paralysed by fear.

Collaborations become laboured, motivation is lost, and inspiration dies. ${ }^{3}$ Our power to transform hurt is limited, and when the pain spills out, we can harm others. ${ }^{4}$ The self-disintegration and guilt are exhausting.

The ravages and side effects of grief cause survivors to retreat, unable to seek help when it is needed most. Prescribed drugs fall short of expectations because when their effects wear off, the pain, defensive behaviour, and realisation of the finality of death remain. ${ }^{5}$ The journey back to feeling like a healthy member of society is challenging.

\section{Reversing the damage}

We know that prolonged social alienation coupled with loss can lead to increased suicides, domestic violence, and irrevocable breakdown of valued business and personal partnerships. ${ }^{6}$ Research shows that the brain loses neural connections as it processes grief and social isolation as severe pain. ${ }^{7}$ With positive feedback, nurturing, and community inclusion, this damage can be reversed. ${ }^{8}$

As professionals, we offer grief counselling to people who have lost one or two relatives in the pandemic. But we have little to offer the healthcare professionals like me who lost at least one friend, relative, or colleague a week to pandemic related death during covid-19 surges. Not people that we have met only once or twice but those with whom we work, love, and play.

But community is a powerful and healing thing. While working in resettlement and prisoner of war release camps in four continents, my husband and I and the teams of people who travelled with us noticed that in general only people who were compassionately and patiently supported thrived. They also grieved their losses, but they were empowered to invest in something outside themselves, such as preparing for medical school, doing research, writing, or mentoring others, and they experienced lasting recovery and reconciliation. Many recovered people paid this forward by helping others. One way we can help is by feeling the other person's needs without judgment.

This is the practice of "radical empathy" that US journalist Isabel Wilkerson describes as: "putting in the work to educate oneself and to listen with a humble heart to understand another's experience from their perspective, not as we imagine we would feel. Radical empathy is not about you and what you think you would do in a situation you have never been in and perhaps never will. It is the kindred connection from a place of deep knowing that opens your spirit to the pain of another as they perceive it."9

\section{Radical empathy in action}

There is an ancient Japanese practice that provides a visual example of radical empathy in action. In kintsugi, people choose to repair treasured pottery or glass objects, emphasising the repair of cracks and breaks with gold and resin. The owners and menders treasure the restored items with self-forgiveness; the obvious damage shows the time and care that went into the repair. ${ }^{10}$

Kintsugi represents healing, resilience, and restoration. It "symbolises the truth that repair requires transformation, that the pristine is less beautiful than the broken-and that the shape of us is impossible to see until its fractured, until a wound, like a crack, runs its length.”10

The pottery does not repair itself. It first has to make itself available, exposed and harmed, with sharp edges and a broken future. The people who love the item, careful not to break it further, consider the cracks as they gently repair, restore, and strengthen it. The gold symbolises trust, permanence, and beauty.

The healers honour, protect, and cherish the item, and it responds by regaining function and beauty. Just as the item is imperfect, so are the healers. Grief, too, is an opportunity to offer empathy, to construct relationships, to notice and honour the beauty and permanence in the fissures and imperfections while gently helping repair and strengthen them. Might we choose to be there for someone who has no one, or when grief changes them and they are angry, sad, and hopeless? Forgiving and extending imperfect but unconditional love to grieving people and ourselves, taking one day at a time, may be all we can offer but it may be enough.

Competing interests: I have read and understood BMJ policy on declaration of interests and have no relevant interests to declare.

Provenance and peer review: Commissioned; not externally peer reviewed. 
1 Sellman L. Covid grief has cracked us open: how clinicians respond could reshape attitudes to bereavement-an essay by Lucy Selman. BMJ2021;374:n1830

2 Dent G. British grief centres mainly around the making of sandwiches. Guardian. 2021. www.theguardian.com/food/2021/feb/19/british-grief-centres-mainly-around-the-making-ofsandwiches-grace-dent

3 Greenhalgh T. Moral uncertainty: a case study of covid-19. Patient education and counseling. 2021. doi: 10.1016/.jpec.2021.07.022. https://www.sciencedirect.com/science/article/pii/S073839912100481X

4 DeGroot JM, Carmack HJ. "It may not be pretty, but it's honest": examining parental grief on the Callapitter blog. Death Stud 2013;37:448-70. doi: 10.1080/07481187.2011.649940 pmid: 24517565

5 Wilson DM, Underwood L, Errasti-lbarrondo B. A scoping research literature review to map the evidence on grief triggers. Soc Sci Med 2021;282:114109. doi: 10.1016/j.socscimed.2021.114109 pmid: 34157614

$6 \mathrm{Ott} \mathrm{CH}$. The impact of complicated grief on mental and physical health at various points in the bereavement process. Death Stud 2003;27:249-72. doi: 10.1080/07481180302887 pmid: 12703505

7 Bayer JB, O'Donnell MB, Cascio CN, Falk EB. Brain sensitivity to exclusion is associated with core network closure. Sci Rep 2018;8:16037. doi: 10.1038/s41598-018-33624-3 pmid: 30375417

8 Schmälzle R, Brook O'Donnell M, Garcia JO, etal. Brain connectivity dynamics during social interaction reflect social network structure. Proc Natl Acad Sci U S A 2017;114:5153-8. doi: 10.1073/pnas.1616130114 pmid: 28465434

9 Holcombe S. Caste: the origins of our discontents. CASTE / A Global Journal on Social Exclusion2020:1:231-4. doi: 10.26812/caste.v112.237

10 Pandey P. The gloden cracked pot. 2018. minutefrommidnight.wordpress.com/2018/06/16/thegloden-cracked-pot/

This article is made freely available for use in accordance with BMJ's website terms and conditions for the duration of the covid-19 pandemic or until otherwise determined by BMI. You may use, download and print the article for any lawful, non-commercial purpose (including text and data mining) provided that all copyright notices and trade marks are retained. 